\title{
CANADIAN SIDE-LIGHTS ON PROSPECTIVE CHANGES IN PENNSYLVANIA PROCEDURE.*
}

An examination of the new rules of the Courts of Ontario, by a Pennsylvania lawyer, must suggest many comparisons with the system of practice with which we are most familiar. To the man of impulsive temperament, if such there be at our Bar, would come the temptation to see in the excellencies of these rules merely an opportunity to hastily condemn the rules of our own courts. The rigid conservative at our Bar, if such there be, would wave these Ontario rules aside with solemn words and dignified gesture. Between those who hastily seize upon and those who sturdily reject, everything new, there is a large class accessible to new ideas and gifted with sufficient knowledge and understanding to appraise their essential value and practical applicability. I take it for granted that the members of the Law Association belong to this class, who in all things seek the middle way, the way of safety, true to the best traditions of our Bar and ever anxious for continuous improvement in our methods of procedure, so that in the struggle for rights between men, it may be more and more certain that right will prevail. Under the influence of some such thoughts as these, I looked through the volume of the Consolidated Rules of Practice of Ontario or to give their full title: "The Rules of Practice and Procedure of the Supreme Court of Ontario (in Civil Matters) prepared by the Honorable Mr. Justice Middleton, under instructions from the Honorable the Attorney-General. Approved by his Honor, the Lieutenant-Governor in Council, under the Judicature Act, Section IO3, to go into effect on the first day of September, I9r3."

The Judicature Act of ${ }^{191} 3,{ }^{1}$ under which these rules were adopted is the last word in Ontario on the subject of the constitution and organization of the courts and of the principles which

*An address before Law Association of Philadelphia, December I9, 1913.

${ }^{1}$ See the Act of 3 George V, cap. Ig. 
govern their practice and procedure. It is a lineal descendant of the Judicature Act of $188 \mathrm{I}$, which, in turn was an offspring of the famous English Judicature Act of 1873 ;-a notable and distinguished pedigree. So excellent has been the working of these Judicature Acts and the Rules of Court promulgated under them, that our own judges in their last revision of our local Rules of Court, have paid them the compliment of adopting a number of their provisions.

Examination of the Ontario Judicature Act shows that it is largely concerned with laying down broad principles, while leaving methods of procedure entirely to the courts. This is a principle of differentiation of function between legislature and courts for which many of the best men at the Pennsylvania Bar have pleaded for many years, and which has often found expression in the reports and debates of the Pennsylvania Bar Association. The attempt to lay down rules of court in acts of legislature has justified the criticism that they hamper rather than promote the efficiency of our procedure. A court which makes its rules may reserve to itself the right to modify them, so that through their too strict interpretation they may not lead to injustice. Where the rule is laid down by the legislature, the sound discretion of the courts cannot be exercised at all and the rule of procedure attains the same dignity and inviolability as a rule of substantive law. The Ontario court in proceeding to formulate and promulgate its rules finds itself unhampered by legislative interference, and is allowed free play for its wisdom to determine how the business of litigation can best be done, so that, to use the words of Rule 183 ,

"A proceeding shall not be defeated by any formal objection, but all necessary amendments shall be made upon proper terms as to costs and otherwise, to secure the advancement of justice, the determining of the real matter in dispute, and the giving of judgment according to the very right and justice of the case."

We, in Pennsylvania, have enjoyed the benefit of the Amendment Act of I 806 and supplementary Acts which, coupled with the common law powers of our courts, have enabled them to fol- 
low the same principles which are so well expressed in this Ontario Rule of Court. It were well if the powers of our courts were still further enlarged in this respect by the abolition of all legislative rules, so that procedure might be regulated entirely by the tribunals before which the causes are litigated. The danger that once existed at common law whereby rules of practice through long use became inflexible need not be feared. Of course, we are occasionally reminded of our imperfections when we observe a judge applying a rule of court as if it were a law of nature, but generally a reasonable discretion is exercised by our courts in their efforts to do justice. The ultimate power to correct an abuse would lie in the legislature and could, in an extreme case of judicial obstinacy, be invoked. In modern times, however, this is not to be feared. Notwithstanding much popular outcry to the contrary, our courts reflect public opinion and desire to accommodate themselves to the views of public policy that public opinion imposes. They will not yield to public pressure unless the pressure is long continuous and based upon a well reasoned and fundamental demand. In the present flux of public opinion on nearly all questions of law, ethics and expediency, our courts are the only stable institution in the midst of a swirling maelstrom of change. They are contributing their proper share to the progress of society, which lies along the resultant of its radical and conservative forces. I would recommend to lawyers radicalism in thought coupled with conservatism in practice. The former is an insurance against the deadening influence of the worship of the status quo; the latter, a safeguard against the hasty destruction of the methods whereby we work out our theories of justice and law; and the combination of the two should result in a sober and scientific but continuous building up on existing foundations, and even in the gradual removal of these foundations, stone by stone, while new material is being substituted, so that the stability of the edifice remains unimpaired.

No doubt the interference of legislatures with the normal development of common law and procedure has served a good purpose and is justified by history. It has continued long enough, 
however, to have fully impressed its lesson upon the mind of all the ministers of justice on the Bench and at the Bar, and it may now be retired in favor of the older method of allowing the law, at least so far as practice and procedure are concerned, to be developed solely through the instrumentality of its experts. No theory is more crude than that which maintains that our legislatures are more expressive of the public will and more responsive to public ideas of right than our courts. The courts are composed of judges and attorneys-at-law, who like all other men are impressed by the influence of the spirit of the time. Occasionally an illustration may be cited to the contrary, such, for example, as the decision of the Supreme Court of the United States in Slocum v. The Insurance Company, ${ }^{2}$ which unquestionably marks a step backward, as pointed out so brilliantly by $\mathrm{Mr}$. Justice Hughes in his dissenting opinion. This case merely illustrates that courts are not perfect, but it by no means proves that they are less perfect than the legislatures. Granting all that may be said against such occasional illustrations of judicial insensibility to contemporary needs or tendencies, it remains true that judges express the ideas of right and expedience dominant in their day, modified, however, by the whole body of law and practice that has been handed down by tradition. For the individual in the pursuit of his own affairs radicalism, modernity and self-expression may be permitted almost indefinitely; for a community of millions of people, social life must perforce be regulated largely by the rules made by the dead and not by the living.

The fundamental characteristic in the organization of the Courts of Ontario is the single court, a Supreme Court consisting of two divisions, the Appellate Division and the High Court Division. The latter is the trial court for all causes.

"Every judge appointed to the Appellate Division or to the High Court Division shall be a judge of the Supreme Court and shall be ex officio a judge of the division of which he is not a member, and, except where it is otherwise expressly

${ }^{2} 228$ U. S. 364 (IgI3). For a criticism of this case, see 6I UNIVERSITY of Pennsylvania Law Review, 673, October I9I3.-Editor. 
provided, all judges of the Supreme Court shall have in all respects equal jurisdiction, power and authority."3

Any judge of the Supreme Court and any retired judge of that court may sit and act as a judge of either of the Divisions of the Supreme Court or perform any official or ministerial act for or on behalf of any judge absent for illness or any other cause, or in place of any other judge whose office has become vacant, or as an additional judge of a Divisional Court."

A distinction is maintained between the judges of the Appellate Division and of the High Court Division, but it is provided that the judges of either of these divisions may sit in the other if necessary, and it is furthermore provided that in addition to the judges who sit continuously in the Appellate Division, five judges of the High Court Division shall annually be selected to sit as appeal judges for one year, so that there shall be at all times at least two Appellate Courts in session, and if necessary an additional temporary Appellate Court may be organized by the judges. ${ }^{5}$

"Where in any action or other proceeding the constitutional validity of any act or enactment of the Parliament of Canada or of this (Ontario) Legislature is brought in question, the same shall not be adjudged to be invalid until after notice has been given to the Attorney-General for Canada and the Attorney-General of Ontario," who "shall be entitled, as of right, to be heard either in person or by counsel, notwithstanding that the Crown is not a party to the action or proceeding."

What a difference it might have made in the decision of Slocum v. The Insurance Company, if this rule had been in force in the Supreme Court of the United States.

The Lieutenant-Governor in Council shall convene in annual Assembly the judges of the Supreme Court,

"for the purpose of considering the operation of this (Judicature) Act and of the Rules (of Court), and the working of

\footnotetext{
'Judicature Act \$8.

- See, ibid. §I4.

See, ibid. §§38, 39.

- Ibid. \$33.

'See note 2 supra.
} 
the offices and the arrangements relative to the duties of the officers of the court, and of enquiring and examining into any defects which may appear to exist in the system of procedure or the administration of justice in the Supreme Court or in any other court, or by any other authority."

and this council shall report amendments or alterations to the Act and any provisions that cannot be carried into effect without legislative authority, for the purpose of improving the administration of justice.

Without going into further details it appears from these and other provisions of the Judicature Act that there is but one court, the judges of which may sit either as trial or as appellate judges; that two Divisions of the court sit to hear appeals; that the chief law officers of the Crown must be heard in all questions affecting the constitutionality of an act of legislature; and that the judges are required to meet in council annually for the purpose of considering the working of their rules and of making such recommendations as in their judgment are advisable.

From time to time voices have been raised in Pennsylvania in favor of some of these provisions, but it has never yet been determined to what extent they are applicable to our State. There is here a fruitful field for inquiry, either by this Association or by the Pennsylvania Bar Association, or by a Commission of lawyers appointed by the Legislature.

Quite recently, the attempt was made to apply one of these principles to the county of Philadelphia by consolidating its courts of Common Pleas by the Act of June II, I9I3. This Consolidation Act, alas, has gone to join the Five Judges Bill in the limbo of unconstitutional stillbirths, and there remains nothing but the faint but fragrant memory of a long-desired possibility. But why shed tears over the early demise of this hope of the family, when an elder brother survives fully able to perform all that was expected of this mourned one. The Act of March 9 , I $885,{ }^{9}$ provides that,

"Ibid. §г13.

ค P. L. 5, §ז. 
"in all counties in which there are two or more courts of Common Pleas, the judges of any of the said courts shall, at the request of any of the other courts of Common Pleas of the same county, have full authority to perform any judicial duty in such other courts, with the same effect as if they were members thereof; provided that nothing in this act shall be construed to entitle a judge so called upon to act for another, to receive extra compensation therefor."

There can be little doubt of the constitutionality of this Act, especially since the Act of March 24, I887, ${ }^{10}$ was held constitutional in Commonwealth v. Bell, ${ }^{11}$ and since the Act of 1885 has been on the books for eighteen years and has been enforced in part by the Philadelphia Rules of Court, and practice. ${ }^{12}$ It seems that the Supreme Court would in considering the constitutionality of such an act take into consideration the fact that it has been on the statute books for a long time unimpeached. ${ }^{13}$

Under the Act of 1885 the judges of Philadelphia could by rule of court, for all practical purposes, while retaining the separate forms of the five courts, amalgamate them into one court and thus produce the result aimed at by the defunct Consolidation Act. Does the Bar at Philadelphia really think the -consolidation of the courts desirable? Then let it petition the courts to act under the Act of 1885 . No one doubts that if the Bar is substantially.unanimous in its request, the Bench will with characteristic grace yield to this demand and grant the relief prayed for.

There being but one court for Ontario it naturally follows that there is but one set of Rules of Court. Here, again, is a subject that has been agitated in Pennsylvania for many years. I recall the labor of love performed by Alexander Simpson, Esq., of this Bar, when in 1896 he prepared a comparative study of all the rules of court of the then existing fifty-one judicial districts of Pennsylvania. The object lesson was not lost and at a

${ }^{10}$ P. L. I4, §r.

$14 \mathrm{~Pa}$. Sup. Ct. 187 ( 1897 ).

${ }^{2}$ See, Phila. Rules 5 and 87 and Rules of Court of 1897, page 9 as amended March 4 , I90I.

${ }^{13}$ See, dictum of Mr. Justice Potter in Gottschall v. Campbell, $234 \mathrm{~Pa}$. 35 I (I9I2). 
subsequent convention (the first and I believe the last) of the judges of Pennsylvania, held in December of the same year, the question of uniformity in the rules of procedure was discussed. From time to time the matter has come up again at meetings of the Pennsylvania Bar Association, but nothing new has been added to the discussion that originally arose.

I have no doubt that it would be possible and practicable for the Supreme and Superior Court judges, in council assembled, to promulgate rules of court for all the courts of Pennsylvania, wherein allowance would be made for the special needs of different localities, due to difference in density of population, in distance from county seats, in convenience of transportation, etc. And I do not share the opinion expressed by some of the judges in the Convention of 1896 that their own local affairs can be best regulated by themselves. The problems are all well known and the appellate courts represent all sections of the State.

Again it may be possible to divide the State into districts, similar to the three districts into which federal jurisdiction is divided, to be organized as District Courts of Common Pleas, composed of all the judges in the District, and being Branches One, Two and Three of the Court of Common Pleas of Pennsylvania. A flexible system might be devised whereby judges may be transferred from one district to the other, as is now sometimes the practice under several acts of Assembly, and whereby a judicial committee of each district, together with the judges of the appellate courts may constitute a Judicial Council performing the functions of the Ontario Judicial Council as above outlined, and making the rules of court and annually reexamining them. Whether such a plan is desirable or practicable or even worthy of consideration, I leave to my brethren of the Bar to be considered by them either in their individual or collective capacity. There is much more to be learned on the practical aspect of this question by study of the judicial systems in jurisdictions other than our own, and I have ventured merely to suggest the topic as a result of my reading of the Ontario Rules of Court. 
How is the bench of Ontario recruited? I am indebted to the Honorable Mr. Justice Riddell of the Supreme Court of Ontario for the following information. ${ }^{14}$ The Minister of Justice, especially if he is not a member of the bar of the particular province for which an appointment is to be made, consults privately such of the bar as he sees fit, regarding available men. Any member of the bar may advocate an appointment, but in most instances it would be fatal for any one desiring a judgeship to solicit it directly or through his friends. No one asking for the position would be deemed worthy of it. The bar in its collective capacity does not express any opinion; the Legislature has nothing to do with the selection, the judges would not think of interfering with the choice or advising as to it. The choice of the man is made by the Minister of Justice and submitted by him to the cabinet. If the cabinet approves, an order in council is passed; if the cabinet disapproves, a further recommendation is made by the Minister of Justice until the cabinet is satisfied. The recommendation of the cabinet is made to the Crown and the appointment is thereupon made.

There is hardly any criticism of judges or courts in Ontario. The spectacle furnished by the United States in which the courts of justice are daily, I might say hourly, held up to criticism, ridicule, contempt and even vituperation excites unbounded surprise across our northern border. The people of Canada are satisfied with their judges and their administration of the law, and yet they have absolutely nothing to do with their selection or appointment. What do the people want? They want justice. If the judge is able and upright, they are satisfied. It is not true that citizens of this county will not be satisfied with the judgment of a judge from another county, whom they have not helped elect. The citizen wants the law of Pennsylvania applied honestly and fairly to his case and he cares nothing about the residence, race, religion or politics of the just judge. We need, therefore, not be too closely wedded to any system of election or appointment, for other methods are just as good. Any method which will end

${ }^{14}$ See 62 University of Pennsylvania Law Review, I7, November Igr3, "The Courts of Ontario."-Editor. 
the disgraceful spectacle which newspaper headlines furnish, such as "Judgeship Won by Advertising," "Nonpartisan Judicial Ballot a Farce," "Recalling Gang-Made Judges," "Governor Drags Courts Into Politics," will be an improvement over methods which invite, or at least make possible, such outbursts. What shall we do? Shall we continue the present method, recently adopted in so many states, of electing judges on a nonpartisan ballot? Shall we return to the former method of appointment by irresponsible political leaders under the guise of a popular election? Shall we frankly abandon the elective system and adopt the New England practice of appointment by the Governor or the Legislature or both? Shall we adopt a system like that of Ontario by appointment through the chief law officer of the State by and with the advice and consent of the cabinet? Shall we adopt the system in vogue in the Jewish Commonwealth according to which the Supreme Sanhedrin appointed commissioners who selected the local judges from among whom the judges of higher courts of Twenty-three and the Supreme Court or Sanhedrin were selected $;^{15}$-a system which might be adapted so as to make our Supreme Court responsible for the appointment of the Common Pleas judges from among whom the appellate courts would be recruited? Whatever the plan, there is room for study and discussion instead of the aimless and thoughtless criticism of our present system.

Another fundamental point of difference between Ontario and Pennsylvania is to be noted in the complete merger of the procedure in law and equity. We have in Pennsylvania long since enjoyed the benefit of the application of equitable principles in common law courts and the administration of both systems by the same judges, but we still recognize chancery procedure as distinguished from practice and procedure at law and our courts have still to consider questions of jurisdiction as between the law and equity side of the Common Pleas Court. All this has been avoided in England since 1873 and in Ontario since I88I. It should be possible for Pennsylvania to study with profit the

\footnotetext{
${ }^{15}$ See, Talmud Babli Sanhedrin 88 b; Maimonides Sanhedrin $2: 7,8$.
} 
experience of these and other jurisdictions and perhaps make further salutary changes in its system.

Looking more closely into the Ontario Rules of Court a comparison with our own Philadelphia Rules at once suggests itself. So far as pleading is concerned, we have done well. Our system is inspired by the same principles of modernization as in other jurisdictions. Our difficulties, such as they are, are due to the fact that the courts have not yet been unfettered by legislative enactment. If all legislative rules of court in Pennsylvania were abolished by the act of legislature and power were conferred on a council of judges to reformulate them, $I$ have no doubt that Pennsylvania would immediately step abreast of the most efficient system in modern times.

In Ontario all actions, whether at law or in equity, are commenced by a writ of summons, are pleaded to issue by a statement of claim, and a statement of defence, and, if necessary, plaintiff's reply; with full power in the court to allow any and all amendments that may be deemed necessary and to bring in by third-party procedure any person or persons who may have any interest in the controversy. All persons may be joined as plaintiffs "in whom any right to relief in respect of or arising out of the same transaction or occurrence or series of transactions or occurrences is alleged to exist, whether jointly, severally or in the alternative, where if such persons brought separate actions any common question of law or fact would arise;" and all persons may be joined as defendants against whom a plaintiff "claims any right to relief, whether jointly, severally or in the alternative; and judgment may be given against one or more of the defendants, according to their respective liabilities." The court has power in the exercise of its discretion to order separate trials, to grant judgment for one or more of the plaintiffs against one or more of the defendants, or make any other order that may be deemed expedient. ${ }^{16}$ It is not necessary that every defendant "shall be interested as to all of the relief claimed, or as to every cause of action included therein" and several causes of

${ }^{18}$ See, Rules 66 and 67. 
action may be included in the same proceeding. ${ }^{17}$ If there are many persons having the same interest, "one or more may sue or be sued, or may be authorized by the Court to defend, on behalf of, or for the benefit of all."18

It becomes possible under the Ontario system to dispose of the interest of all parties to a controversy in one action, and all differences between law and equity, contract and tort, right to property or right to damages are merged in the fact that the controversy arises out of the same transaction and that all of the parties have an interest in the whole or some part of it. The effect of this rule is to prevent multiplicity of actions and reduce the amount of litigation arising out of a single transaction.

It was feared at one time by the Bar of Ontario that this and other rules making for simplicity and speed would affect the business of the Bar, but the result has proved quite the contrary. The knowledge that all controversies arising out of a single transaction may be disposed of at one trial swiftly, justly and certainly has encouraged litigation. I have before me the calendar of the Supreme Court of Ontario, Appellate Division, for appeals entered for the session of one month commencing April 7, I9I3. There are sixty-nine cases on the list, fifty-one of which are from judgments entered during I9I3. That is to say, within three months of the date of the argument on appeal; thirteen within six months and five older cases antedating this period. Of the cases in I9I3, five are less than a month old since judgment, thirty-one are less than two months old. The Appellate Divisions of Ontario hear and dispose of about eight hundred cases per anmum, whereas the average record of the Supreme and Superior Courts of Pennsylvania is about twelve hundred cases per anmum. It will be seen, therefore, that in Ontario with a population of about three millions as against a population of eight millions in Pennsylvania, the appellate courts dispose of nearly twice as many cases in proportion to population as the appellate courts of Pennsylvania. This should allay the fears

\footnotetext{
"See, Rules 68 and 69.

28 See, Rule 75.
} 
of members of the Pennsylvania Bar that simplicity and speed would reduce the emoluments of the profession. The simpler the procedure and the more expeditious the trial the greater will be the interest of the public in this method of adjusting its difficulties and the greater the amount of business that the Bar will be called upon to administer.

One of the startling methods for saving time is that laid down in one of the Ontario Rules ${ }^{19}$

"(I) On all appeals or hearings in the nature of appeals, and on all motions for a new trial, the Court or Judge appealed to shall have the powers as to amendment and otherwise of the Court, Judge or officer appealed from, and full discretionary power to receive further evidence, either by affidavit, oral examination before the Court, or Judge appealed to or as may be directed. (2) Such further evidence may be given without special leave as to matters which have occurred after the date of the judgment, order or decision from which the appeal is brought. (3) Upon appeals from a judgment at the trial, such further evidence (save as mentioned in sub-section (2) shall be admitted on special grounds only, and not without.leave of the Court."

Under this rule, the court on appeal will hear testimony if necessary to supplement the record from the trial court instead of sending the case back for retrial with all the attendant delay, cost and disappointment.

Where a plaintiff has filed a statement of claim or defendant a statement of defence either party may be cross-examined by the other prior to the trial upon the allegation in their respective pleadings. I am further told by Mr. Justice Riddell that although this rule does not meet with universal satisfaction, it results in the disposition of at least one-third of all litigation without trial by reason of the disclosure that parties are obliged to make of the very essence of their case. The principle that seems to prevail in Ontario is that no litigant shall be permitted to take advantage of anything except the real merits of his case. 'If a man swears to facts in an affidavit of defence which, if true, would constitute a good defence, the plaintiff in Penn-

\footnotetext{
${ }^{19}$ See, Rule 232.
} 
sylvania is for the time being helpless and the case is set down for trial. In Ontario the plaintiff may cross-examine the defendant upon his statement of defence and thus elicit the fact that the defence is merely colorable and that the proofs at the trial would fall short of the defence set forth in the pleading. Upon the statement of defence and the cross-examination the matter may then be brought before the court by a proceeding similar to our rule for judgment for want of a sufficient affidavit of defence, and the court in granting or refusing judgment will consider the sufficiency of the statement of defence in the light of the cross-examination of the defendant and give judgment accordingly. The same rule applies to a cross-examination of the plaintiff upon his statement of claim. ${ }^{20}$

In Kibbe v. McKinley, ${ }^{21}$ the late President Judge Finletter decided that it is not unreasonable to require claimant in interpleader to submit to examination upon his affidavit of claim, for if the claim is a just one the preliminary examination will establish it and no one should be allowed to profit by an unjust claim. There is, therefore, nothing in the objection that he is compelled to disclose his evidence of ownership. If this is a sound and good rule of practice under the Interpleader Act, why should it not be extended to all pleadings in all actions?

A series of Rules looking to a similar result are those relating to the production of documents. ${ }^{22}$ With us, documents may be ordered to be produced at the trial, or a notice to produce at the trial may be given, but such production cannot be enforced before the trial unless the issue is forgery or unless the pleadings cannot be prepared without such inspection, or, generally speaking, unless the party calling for the documents has a common interest in them with the party in whose possession they are. In Ontario the rule ${ }^{23}$ is that,

"Each party after the defence is delivered, or an issue has been filed, may by notice require the other within ten days

${ }^{*}$ See, Rule 327, etc.

21 o Phila. Rep. 232 (Pa. I889).

See, Rules 348 , etc.

See, Rule 348. 
to make discovery on oath of the documents which are or have been in his possession or power relating to any matter in question in the action; and produce and deposit the same with the proper officer for the usual purpose."

Documents in the possession of persons not parties to the action may be compelled to be produced for inspection. ${ }^{24}$ If the right to discovery or inspection depends upon the determination of some question in dispute, the court may try and determine the question in dispute before deciding as to the right of discovery or inspection. ${ }^{25}$

A word with reference to jury trials. The Judicature Act ${ }^{26}$ provides that,

"actions of libel, slander, criminal conversation,. seduction, malicious arrest, malicious prosecution and false imprisonment shall be tried by a jury unless the parties in person or by their solicitors or counsel waive such trial."

Actions for damages for injuries by reason of the default of a municipal corporation in not keeping in repair a highway or bridge shall be tried by a judge without a jury. ${ }^{27}$ Subject to the Rules of Court and except where otherwise expressly provided by the Judicature Act, all issues of fact shall be tried and all damages shall be assessed by the judge without the intervention of a jury, but the judge may direct a jury trial. ${ }^{28}$ If a party desires a jury trial, notice must be given, but notwithstanding such notice the judge presiding at the trial may dispense with the jury. ${ }^{29}$ It shall be sufficient if ten of the jurors agree and they may render a verdict, and if more questions than one are submitted to the jury it shall not be necessary that the same ten jurors shall agree to every answer. ${ }^{30}$ If a juror dies or becomes otherwise incapacitated from acting, the judge may discharge the

\footnotetext{
${ }^{24}$ See, Rule 350.

${ }^{25}$ See, Rule 352.

${ }^{\infty} \$ 53$.

${ }^{2}$ See, $\$ 54$

See, \$55.

${ }^{20}$ See, \$56.

${ }^{20}$ See, $\$ 58$.
} 
juror and proceed with eleven jurors, ten of whom may give the verdict or answer the questions submitted to the jury. ${ }^{31}$ The jury shall not give a general verdict if directed by the court not to do so. They shall give a special verdict if the court so directs. ${ }^{32}$ Except in an action for libel ${ }^{\mathbf{3 3}}$ the judge may direct the jury to answer any questions or facts put to them by him and the jury shall answer the questions and not give any verdict. ${ }^{34}$

"The court may obtain the assistance of merchants, engineers, accountants, actuaries, or scientific persons, in such way as it thinks fit, to enable it to determine any matter of fact in question in any cause or proceeding, and may act on the certificate of such persons." ${ }^{35}$

It may be difficult to realize that these provisions of the Judicature Act and the Rules of Court of Ontario have been promulgated in a country which adopted the common law and procedure of England in I792, and has since then flourished under that system. In England, the jury system performed an inestimable service in the development of the English constitution and the maintenance of the liberties of the people. The English colonies, children of the mother country, inherited this system. In the course of time England and her colonies realized what even Blackstone, ${ }^{36}$ despite his eulogy of the jury foresaw, that this institution; notwithstanding its antiquity, respectability and honorable achievement, no longer satisfied the demands of justice, and accordingly they proceeded to modify it and now we have the interesting spectacle of an English country practically abolishing trial by jury and substituting trial by the court, except in certain classes of torts. The American states were also children of the mother country, but nearly a century and a half ago they repudiated her parental control, and established them-

"See, §59.

s See, \$60.

${ }^{23}$ Until 1913 a jury could not be directed to answer questions in actions for slander, crim. con., seduction, malicious arrest, malicious prosecution and false imprisonment.

"See, §6r.

${ }^{25}$ Rule 268.

* See, 3 Bla. Comm. 38I. 
selves as free and independent states. What they took from England before that time they have clung to with much tenacity, and although they realize the imperfections of the jury system they seem to find it difficult to attack the problem with anything like the boldness shown by England and her colonies, because of the bar of the state and federal constitutions. It will probably require the experience of many, many more years before the Seventh Amendment to our federal Constitution will be changed. In the meantime it seems to be the policy of the more progressive states to limit the right of trial by jury by requirements that jury trial must be asked for, that jury fees must be deposited and by encouraging the bar to agree to accustom the people to trial by the court without a jury by agreement of the parties. That the jury in civil cases is an anachronism and an absurdity has been frequently asserted, especially by those whose experience in courts of equity, courts of bankruptcy and before masters and referees have convinced them that the issues in civil cases can be more effectively disposed of by trained experts than by jurymen chosen at large. In Ontario the court ${ }^{37}$ calls in what is virtually a jury of experts, for the purpose of assisting it in determining matters of fact, and gives to the certificate of such persons the weight to which an expert opinion by a disinterested and competent person is reasonably entitled.

It is impossible within the limits of this address to point out all of the significant rules and points of procedure in force in Ontario. Those who are interested in the further improvement of our own system, notwithstanding its many already existing excellencies, will do well to study the system in this neighboring province.

We have passed the age when progress with us is unconscious, when we go on like creatures living in the state of nature, subject merely to the forces that impel us from without. In the field of jurisprudence we have become self-conscious and even sophisticated and we realize the possibility within certain limits of making improvement as the result of deliberate experiment.

"Under Rule 268. 
This is the method of the scientist, the method by which facts are examined, working hypotheses proposed and conclusions reached as a result of an attempt to explain all existing facts by general underlying laws. In our effort to improve our legal system we need the method of discovery for a long time to come. This is virtually a method for the collection and examination . of the data of experience here and elsewhere in order that from them principles may be discovered which may again be formulated in the terms of new methods. It is a system of legal education not limited however, as heretofore, to the education of applicants for admission to the Bar but to the education of the Bar itself. According to our system, the Bar neglects its students as soon as they have been sworn in. Is it impossible for the Bar to establish an equivalent to the system of post graduate instruction, whereby the minds of its own members may be enriched and enlightened by the continual study not merely of the principles and practice of the law in their own jurisdiction for immediate practical results in litigation, but for the study of the experiences of other places and other nations, in order that provincialism may be replaced by urbanity and our views of principles and methods may be enlarged and refined?

I am afraid that we do not have enough men at our Bar who are interested in the science of law. There are many excellent lawyers and judges, but few jurists, although by courtesy of the newspapers all judges are so called. The science of the law is sometimes taught in the post graduate schools of the universities, but not as a rule in the schools of law. The purpose of the schools of law has been and is, to graduate lawyers trained in the methods of legal thought and legal reasoning with a fair knowledge of the principles of law which they shall be called upon to apply in practice. There is a great field here as yet unbroken. Eventually the State will realize its importance, and reward those who devote themselves to it by giving them an opportunity to translate into life the results of their so-called unpractical studies. That will be the day when the legislation will be directed by scientifically trained jurists instead of the untrained representatives of the people. Year after year there is pointed out to us the folly 
and absurdity of much of our legislation. We are shown the accumulation of freak laws and inconsistencies and redundancies and contradictions, and the enormous waste not only of the public time and funds required to produce this crop of thistles, but the incalculable waste which results from the attempt to apply and administer such laws. Legislative reference bureaus of all sorts, such as the one established in Pennsylvania in I9o9, somewhat minimize this evil. It is not to be expected that any substantial result of permanent value will be obtained until it is generally realized that law, whether it be an art or a science, requires not only special skill in its administration by the Bar and interpretation by the Bench, but and above all the highest skill and wisdom and knowledge by the legislators who make it.

In Ontario they have a method of nipping in the bud much bad legislation, by a system which has not been expanded to its full possibilities. Chapter Fifty-two ${ }^{38}$ provides, that the judges shall be paid one thousand dollars in addition to their salary for the performance of duties assigned to them by the provincial legislature, outside of their ordinary duties, such as matters connected with Provincial Election, Estate Bills, Regulations to Govern the Practice of the Surrogate Courts, etc. The practice is to refer all Estate Acts ${ }^{39}$ to two judges for an opinion on their justice and expediency. By Chapter Eighty-four it is provided that the Government, that is, the Lieutenant Governor in Council, may refer to the court for hearing or consideration "any matter which he thinks proper to refer" for an opinion as in an ordinary action. If the question is the constitutional validity of an act of the legislature or a proposed act, either before or after the question arises in an actual case, the Attorney-General of Canada must have notice and a right to be heard, and the court may direct any interest to be notified with the right to be heard, or request some counsel to represent such interest. The opinion of the court is a judgment subject to appeal as in an ordinary action.

How much chaff could be eliminated from our legislative

"See, R. S. O. 1897.

"I. e. private acts changing the legal effect of wills, settlements, etc. 
hopper before being ground out as legislation, if some such practice were in force here under a constitutional amendment to Article V, Section Twenty-one $!^{40}$

Much might be said in favor of a legislative system differing entirely from our own, and much might be said for a system of legislation by experts, as opposed to the present system of untrained representatives of the people. On the other hand the representative system is not to be despised. Whoever our legislators may be, it will be conceded that participation in the great work of making a people's laws should require some proper preparation, for the words of the Jewish Master of Jurisprudence ${ }^{41}$ are still true today, "prepare thyself by study of the law, for knowledge of it is not inherited." A most encouraging sign of the times is the tendency to rely on the expert, and the willingness of the citizen to waive his inalienable and constitutional right to muddle all things by the expression of his views and the exercise of his power. We shall no doubt reach the day when it will be understood that the untrained citizen assisted by the otherwise unoccupied politician, are not divinely inspired instruments for expressing the will of the people and that law making as well as law administration had better be left to the professional experts, whose training makes for efficiency.

David Werner Amram.

University of Pennsylvania.

${ }^{10}$ See I P. \& L. Dig. of Laws, I30 (and Ed.).

Rabbi Jose ben Halafta, cited in Mishnah Aboth 2: I7. 